\title{
Youtube as the Learning Media to Improve the Speaking Skill in Expression Orale Course
}

\author{
Nurilam Harianja $^{1}$--- Hesti Fibriasari ${ }^{2^{*}}$ \\ ${ }^{\prime}$ French Education Departement, Faculty of Language and Arts, Universitas Negeri Medan, Indonesia. \\ 'Jalan Willem Iskandar Pasar V Medan Estate, Medan, Sumatera Utara, Indonesia. \\ Email:hesti@unimed.ac.id
}

\begin{abstract}
This research aims to improve the speaking skill for the students who take the oral expression course. The objects of this research are the students in the French department, especially who take the expression oral course 3. It is found that the previous class couldn't improve the speaking skill of the students very well. Most of the students were not very interested in the learning process. From the questionnaire given, it is found that they were bored because nothing was interesting and exciting in the class. The media they used was only a book from the lecturer. So, the making learning media of expression Orale by using YouTube aims to help learners to understand French with the local cultural situation. Making learning media of speaking using TouTube based on local culture is very important to improve the learning abilities of French. This video will also be handy for French tourists who visit Indonesia, especially Medan because this video will present the real situation in Medan. The research method uses Research and Development which is carried out in the French Language Education Study Program. The results of this research show that the students are enthusiastic in the learning process, their ability in speaking is also improving, and the media supports the learning process very good.
\end{abstract}

Keywords: Learning media, Speaking skill, Video, TouTube, French.

Licensed: This work is licensed under a Creative Commons Attribution 4.o License.

Funding: This study received no specific financial support.

Competing Interests: The authors declare that they have no competing interests.

\section{Introduction}

In this millennium era, information and computer technology (ICT) is used by foreign language learning by creating paid learning platforms until free of charge. The use of ICT in the world of education is extensive. The teaching and learning process becomes more creative and does not use conventional media. The purpose of ICT in foreign language learning is with an unlimited range, so the learning process is not always in the classroom, but it can be done anywhere and anytime. Teachers use this situation by creating creative ideas to make learning materials by utilizing ICT that can add treasures of foreign language learning. Teachers of foreign languages seek to make ICT-based learning media as an effort to improve the ability of foreign language learners in the competence of reading, writing, speaking and listening.

Four-language competencies in French consist of comprehension orale, expression orale, comprehension, and production script. French is a language that is studied by Indonesian people formally and informally. The teaching and learning process aims to enable teachers to convey information that can be understood and applied to daily life. Teachers try to create learning situations that are not monotonous by involving learners in the learning process. Based on the results of interviews with learners and instructors in French Language Study Program Unimed, the ability of students to speak still has difficulties in vocabulary problems and the 
creative ability of learners to describe a situation. Learners imagine a position that is not true as if the learners are in France even though they have never visited France and know French culture only through cyberspace and literature.

One example when a learner is going to do the buying and selling process in a traditional market, the learner will find difficult to apply the theories obtained in the class about buying and selling conversations in the market which are not suitable to Indonesian culture. The situation and culture of traditional markets in Indonesia are undoubtedly different from traditional markets in France. Therefore it is essential to make learning media based on local culture. Making this learning media aims to help learners understand French with the domestic cultural situation by using learning media of YouTube.

\section{A. Formulation of the Problem}

The formulation of the issues in this study is:

1. Which suitable media that can be applied to the Production Orale course?

2. How can students improve their speaking skills by using media based on local culture?

3. How is the application of learning media by using YouTube in Production Orale courses?

\section{B. Research Objective}

The research objectives of this study are:

1. To know the media following the learning of Indonesian culture that can be applied in the Production Orale course.

2. To see the improvement of students' speaking skills by using media based on local culture.

3. The application of learning media by using YouTube is at the Production Orale course.

\section{Literature Review}

A. Learning Media

The teaching and learning process with the existence of two-way communication is between instructors and learners by using learning tools. Learning tools in the form of teaching material, media, model and method become a facilitator to deliver messages or learning material. Learning material which is given to learners is strongly influenced by the ability of learners with the existence of learning resource that can make learners can learn independently following visual, auditory and kinesthetic abilities possessed by learners. The determination of the right method selection should consider the right aspects to be achieved, namely referring to the outline of the learning program which is divided into two types:

1. The learning process is able to encourage students to organize and to fill new experiences with guidance on the past that has been experienced. Examples: question and answer exercises, interview, consultation, sensitivity exercises, etc.

2. The learning process is designed to increase the transfer of new knowledge, new experiences, and new skills so that they can encourage each of them to achieve the maximum expertise they want, what they need, and the skills required. Example: learning to use a computer.

\section{B. Toutube}

The use of ICT-based learning media is beneficial for learners to learn foreign languages online. Learning media are such as blogs, e-learning, and YouTube.

Along with the development of the era that made the competition in term of information technology, YouTube comes with all the conveniences provided. YouTube is a website in the form of a popular video sharing service that allows users to load, watch and share video clips for free. Since being launched in December 2005 and acquired by Google in 2006, YouTube users have continued to increase to more than one billion per day. The latest statistic shows that more than 4 billion YouTube videos are watched every day. This media is prevalent because it can function as a source of information, entertainment, and self-expression that can be widely accessed in 24 hours in 39 countries in 54 languages. In 2011, YouTube showed more than 1 trillion or nearly 140 views for each person on this earth. (www.YouTube.com). YouTube is a web-based file sharing service that allows individuals to build public profiles, to determine a list of other users to share videos and to see a list of connections/content made by others.

\section{Previous Research}

Learning model based on Information and Communication Technology is beneficial in the process of learning French because PRAAT software is available to improve the speaking skills of French students in Audition Pronunciation course so that they can have articulation like native speakers do (Fibriasari, 2015). To see mistakes that are often made by students is when connecting the word liaison when reading the text. Enhancing the ability of Unimed French students to understand thoroughly and correctly should be following applicable rules. French Language Study Program Unimed presents Comprehension écrite I course at the beginning of the semester and is adjusted to the European standard curriculum (CECR) DELF A 1 (Fibriasari, 2016). The use of Information and Computer Technology in learning aims to improve vocabulary mastery. By 
using the TV5 Monde website, it is expected that learners will find it easier to learn French vocabulary (Fibriasari, 2017).

\section{Research Method}

This study uses the R \& D (Research and Development) approach. Research on R \& D is a necessary research activity to obtain information on user needs (needs assessment), then development activities are carried out to produce products and test the effectiveness of the products. This study uses the R \& D approach because in this study will deliver products in the form of interactive learning media on Static Promotion course. Borg and Gall revealed that there are 10 steps in the development research process, according to Borg and Gall can be done more merely involving 5 main steps, namely: (1) Analyzing the products to be developed; (2) Developing the initial product; (3) Expert validation and revision; (4) Small-scale field trials and product revisions; (5) Large-scale field trials and final products. The steps in the development procedure can be described as follows.

The research was conducted at the French Language Education Study Program Unimed. The time of the study was done in June-November 2018. The research subjects in this development research consisted of 2 media experts, two material experts, ten students in small-scale field trials and in large-scale field trials comprised of all students who were taking Production oral 1 courses consist of 30 students. Data collection techniques used in this study are observation, interviews, and questionnaires. Observations were made when the research was carried out to obtain data as a basis for conducting research and development. Interviews were conducted with Production lecturers and students to gather data on needs in research and development. Questionnaires were used to obtain assessment data on the quality of media feasibility which is developed according to media experts, material experts and students in small-scale field trials and large-scale field trials.

\section{Discussion}

a. Data Collection

In this step was conducted a preliminary study with a documentation method to find materials which are available for the third semester. The data obtained included the material contained in the third semester. For the needs analysis, questionnaire and interview methods were used - survey for needs analysis distributed to French students. A short interview was conducted on French lecturers who taught expression orale course at French Language Study Program Unimed. This thing is intended to obtain information about the needs of lecturers and students on the third-semester French language learning video media on speaking skills.

b. Product Design

In this step, it starts with designing the appropriate material that will be included in the expression orale learning video and then designing the product that will be created, namely media of learning videos for French expression orale in the third semester. At this stage, the researcher makes a synopsis, script or production script, and scenario. After that, it is proceeding with the process of shooting and editing video. Next is processing video and graphics into learning display of French expression oral.

c. Validation

In the validation stage, it is selected French linguists who are considered capable of knowing the suitability of the product design that has been made. This thing is done to find out the weaknesses and lack. According to Sugiyono (2010) design validation is an activation process to assess whether the product design, in this case, the new work system will be rationally more effective than the old or not. From the opinion above, it was concluded that the educational products resulting from development must go through an assessment process before being implemented into the field. Also, product validation can be done by presenting several experienced experts to assess the newly designed product. In validating a product according to Sugiyono (2010) each expert is asked to evaluate the design, so that the weaknesses and strengths can be identified. A validation sheet will be used to test the product. This validation test sheet can help determine the media model created. This validation sheet contains aspects of French learning video of expression orale course during the third semester on speaking skills. This validation test sheet is filled by expert lecturers. In addition to providing corrections, this expert lecturer is also expected to provide input and suggestions for improvement of the speech evaluation tool that has been made. So the products which are produced have better quality and feasibility than before.

\section{d. Design Revision}

After knowing the weaknesses and some inputs from media experts, the researcher conducted a design revision according to the advice of these experts, resulting in a design that was ready to be implemented.

\section{Conclusion}

Based on the result of product research and development concluded: 
1. Based on the needs analysis through questionnaires for students and interviews with French lecturers, it can be seen that the French learning video media for semester three is needed as a medium for learning to speak. The videos needed are in the form of videos which are short and based on local culture.

2. The result of this media research and development are learning videos of French Expression orale for the third semester consisting of several themes: faire des achats, transportation with a duration of three to five minutes.

\section{References}

Fibriasari, H. (2015). The audition prononciation learning based on multimedia in French section of Unimed. Proceeding on Edicational Creativity and Innovation in Prespectives of The ASEAN-China Relations. 5-6 November.2015, Kang Ming Hotel, Beijing. Hal. pp: 299-307.

Fibriasari, H. (2016). Improvement of the learning model of hearing pronunciation. Proceeding on International Conference on French French: in Games Linguistic, Political, Economic and Culture. November 3, 2016. UPI. Bandung.

Fibriasari, H. (2017). Prosodic frequency in signaling linguistic distinctions at UNIMED first year non-native French students. International Journal of Humanities and Social Science, 6(10): 118-124.

Sugiyono, P. D. (2010). Research and development methods. Bandung: Alfabeta. 